\title{
Novel Hopanoic Acid and Depside from the Lichen
}

\author{
Dirinaria applanata
}

\section{Nguyen Trong Tuan $\oplus^{1^{*}}$, Mai Van Hieu $\oplus^{1}$, Nguyen Quoc Chau Thanh $\oplus^{1,3}$, Huynh Van Loi $\oplus^{1}$, Lai Huu Nghia ${ }^{1}$, Tran Thi Tuyet Hoa $^{2}$ and Kanaori Kenji ${ }^{3}$}

\author{
${ }^{1}$ Department of Chemistry, College of Natural Sciences, Can Tho University, Vietnam \\ ${ }^{2}$ Department of Aquatic Pathology, College of Aquaculture and Fisheries, Can Tho University, Vietnam \\ ${ }^{3}$ Faculty of Molecular Chemistry and Engineering, Kyoto Institute of Technology, Japan
}

(Received October 12, 2019; Revised December 12, 2019; Accepted December 13, 2019)

\begin{abstract}
From the extract of lichen Dirinaria applanata, two hopane derivatives including $1 \beta$-acetoxy- $3 \beta$ hydroxy-21 $\alpha$-hopan-29-oic acid (1), hopane-3 $\beta, 6 \beta, 21 \alpha$-triol (2) and a depside namely 2- $O^{\prime}$ methylnordivaricatic acid (3) were isolated and identified by extensive analyzing 1D-NMR, 2D-NMR, HRESIMS, and FT-IR. Notably, compound $\mathbf{1}$ and $\mathbf{3}$ were novel compounds while compound $\mathbf{2}$ was isolated from this lichen species for the first time.
\end{abstract}

Keywords: Dirinaria applanata; lichen; hopan-29-oic acid; depside. () 2020 ACG Publications. All rights reserved.

\section{Introduction}

Lichens are symbiotic organisms which usually include fungi and photosynthesis organisms (alga or cyanobacteria) [1]. Previous studies on lichens composition unfolded the existence of diverse secondary metabolites including monocyclic phenols, depsides, depsidones, xanthones and terpenoids [2]. Moreover, the investigation of biological activities indicated that lichens and its composition exhibited a wide range of biological activities such as antioxidant, anticancer, antibacterial, and antifungal, antiviral and enzyme inhibitory [3-5]. Dirinaria applanata is a foliose lichen, which widely distributes in tropical areas. Previous chemical investigation showed that $D$. applanata contained antranorin, divaricatinic acid and its ester derivatives, methyl haematommate, methyl $\beta$ orcinolcarboxylate, ramalinic acid, lichenxanthones, tannins, and terpenes [6-8]. In continuing to explore the chemical composition of D. applanata, we herein reported the structural elucidation of two hopane derivatives and a depside.

\footnotetext{
*Corresponding author: Email: trongtuan@ctu.edu.vn Phone: 084-918-858131
} 


\section{Materials and Methods}

\subsection{General Experimental Procedures}

NMR spectra were acquired on Bruker Advance $500 \mathrm{MHz}$ and Bruker Advance $600 \mathrm{MHz}$ using TMS as an internal standard. FT-IR was conducted using $\mathrm{KBr}$ pellet method on Thermo Nicolet 6700 . HRESI-MS observation was performed on a Bruker MicrOTOF-Q mass spectrometer and on a SCIEX X500R-QTOF. The melting point was recorded using glass capillaries without calibration on Stuart Scientific SMP3. Optical rotation instrument was SEPA-200 (Horiba, Japan) with cell length: $50 \mathrm{~mm}$. Silica gel 60 (Merck, 230-400 mesh ASTM) and RP-18 (Sigma-Aldrich) were packed for column chromatography (CC). Precoated silica gel 60 F254 plates (Merck) were used for analytical TLC.

\subsection{Lichen Sample}

The lichen thallus was collected in Can Tho University campus II, Can Tho city, Vietnam from January to April 2018 by observing thallus morphology and comparing with the literature [9]. The identification was conducted by Dr. Ngo Thanh Phong, Department of Biology, College of Natural Sciences, Dr. Dang Minh Quan, Department of Biology Education, Can Tho University, and Dr. Vo Thi Phi Giao, Faculty of Biology, HCM University of Science. A voucher specimen was deposited in Laboratory of Plant Biology Department of Biology, Can Tho University, Vietnam under number (Li012018-CT001) and in Herbarium of University of Science, Ho Chi Minh City, Vietnam National University (PHH) with the voucher specimen number PHH0011078. Lichen thallus was kept in paper bags and was naturally dried at room temperature.

\subsection{Extraction and Isolation}

Lichen material was finely powdered $(1.28 \mathrm{~kg})$ and extracted with methanol $(3 \times 5 \mathrm{~L})$ at room temperature. The solvent was evaporated using rotary evaporator to obtain methanol extract $(210 \mathrm{~g})$. The methanol extract was well-mixed with water followed by shaking with hexane and ethyl acetate to give a hexane extract $(88 \mathrm{~g})$ and ethyl acetate extract $(76 \mathrm{~g})$, respectively. The remaining water layer was condensed to afford water extract $(32 \mathrm{~g})$.

The ethyl acetate $(30 \mathrm{~g})$ was separated to 10 fractions (EA1-10) by flash column chromatography eluted with hexane:EtOAc (5:1 to 0:10) and EtOAc:MeOH (10:1 to 2:1). Fraction EA3 was applied to column chromatography and was washed with $\mathrm{CH}_{2} \mathrm{Cl}_{2}: \mathrm{MeOH}(0: 10$ to $10: 0)$ to afford 8 fractions (EA3.1-3.8). Compound $1(79 \mathrm{mg})$ was obtained after purifying fraction EA.3.4 by hexane: $\mathrm{CH}_{2} \mathrm{Cl}_{2}$ (2:8 to 0:10) and recrystallizing in $\mathrm{CH}_{2} \mathrm{Cl}_{2}$. Solid residue in fraction EA.3.3 was washed and repeatedly recrystallized in $\mathrm{CH}_{2} \mathrm{Cl}_{2}$ to give a white solid named as compound $2(10.5 \mathrm{mg})$. The water residue $(10 \mathrm{~g})$ was subjected to RP-18 column chromatography and washed with $\mathrm{H}_{2} \mathrm{O}: \mathrm{MeOH}$ (10:0 to 0:10) to give four fractions (W1-4). Repeated purifying fraction W-3 (0.67 g) by using $\mathrm{H}_{2} \mathrm{O}: \mathrm{MeOH}$ (3:7) on RP-18 afforded compound $\mathbf{3}$ (13.5 mg) as a solid.

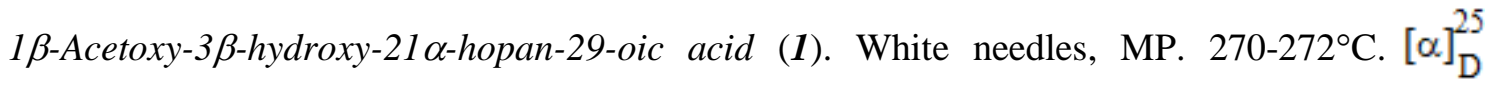
$+12.0\left(\mathrm{c}=0.267, \mathrm{CHCl}_{3}\right)$. HR-ESI-MS $m / z:[\mathrm{M}-\mathrm{H}]^{-}=515.3734$ (calcd. for $\left.\mathrm{C}_{32} \mathrm{H}_{53} \mathrm{O}_{5}{ }^{-}, 515.3736\right)$. IR (KBr) $v_{\max }\left(\mathrm{cm}^{-1}\right):=3418,2949,1732,1716,1467,1376,1248,1184,1043,1019 .{ }^{1} \mathrm{H}-\mathrm{NMR}$ and ${ }^{13} \mathrm{C}-$ NMR (see Table 1).

$21 \alpha$-Hopane-3 $\beta, 6 \beta$, 22-triol (2). White solid, MP. $287-289^{\circ} \mathrm{C} .[\alpha]_{\mathrm{D}}^{25}+6.0\left(\mathrm{c}=0.2, \mathrm{CHCl}_{3}\right)$. IR $v_{\max }\left(\mathrm{cm}^{-1}\right):=3414,2944,2851,1472,1387,669 .{ }^{1} \mathrm{H}-\mathrm{NMR}\left(600 \mathrm{MHz}, \mathrm{CDCl}_{3}\right): \delta(\mathrm{ppm})=0.69(1 \mathrm{H}$, $m, \mathrm{H}-5), 0.77$ (3H, $s, \mathrm{C}-28), 0.91$ (3H, $s, \mathrm{C}-27), 0.93(1 \mathrm{H}, m, \mathrm{H}-19 \alpha), 0.97(1 \mathrm{H}, m, \mathrm{H}-19 \beta), 1.06$ (3H, $s, \mathrm{H}-23), 1.16(3 \mathrm{H}, s, \mathrm{H}-24), 1.18(3 \mathrm{H}, s, \mathrm{H}-29), 1.19(3 \mathrm{H}, s, \mathrm{H}-25), 1.21(3 \mathrm{H}, s, \mathrm{H}-30), 1.24(1 \mathrm{H}, m$, $\mathrm{H}-15 \alpha), 1.26$ (1H, $m, \mathrm{H}-9), 1.30(3 \mathrm{H}, s, \mathrm{H}-26), 1.44(1 \mathrm{H}, m, \mathrm{H}-15 \beta), 1.45(2 \mathrm{H}, m, \mathrm{H}-11), 1.46(1 \mathrm{H}, m$, $\mathrm{H}-12 \alpha), 1.46(1 \mathrm{H}, m, \mathrm{H}-17), 1.47(1 \mathrm{H}, m, \mathrm{H}-7 \beta), 1.47(1 \mathrm{H}, m, \mathrm{H}-13), 1.50(1 \mathrm{H}, m, \mathrm{H}-20 \alpha), 1.57(1 \mathrm{H}$, $m, \mathrm{H}-2 \alpha), 1.57(1 \mathrm{H}, m, \mathrm{H}-12 \beta), 1.55(1 \mathrm{H}, m, \mathrm{H}-19 \alpha), 1.58(1 \mathrm{H}, m, \mathrm{H}-16 \alpha), 1.64(1 \mathrm{H}, m, \mathrm{H}-2 \beta), 1.67$ $(1 \mathrm{H}, m, \mathrm{H}-1 \beta), 1.72(1 \mathrm{H}, m, \mathrm{H}-7 \alpha), 1.76(1 \mathrm{H}, m, \mathrm{H}-20 \beta), 1.94(1 \mathrm{H}, m, \mathrm{H}-16 \beta), 2.23(1 \mathrm{H}, d t, 10.8$ \& 
$9.0 \mathrm{~Hz}, \mathrm{H}-21), 3.14(1 \mathrm{H}, m, \mathrm{H}-3), 4.55(1 \mathrm{H}, s, \mathrm{H}-6) .{ }^{13} \mathrm{C}-\mathrm{NMR}\left(150 \mathrm{MHz}, \mathrm{CDCl}_{3}\right): \delta(\mathrm{ppm})=16.3(\mathrm{C}-$ 28), 16.9 (C-24), 17.0 (C-27), 17.3 (C-26), 17.6 (C-25), 21.1 (C-12), 21.9 (C-16), 24.2 (C-11), 26.6 (C-20), 27.6 (C-2) 27.7 (C-23), 28.8 (C-29), 30.9 (C-30), 34.5 (C-15), 36.7 (C-10), 39.6 (C-4), 40.7 (C-14), 40.8 (C-1), 41.0 (C-7), 41.3 (C-19), 42.0 (C-8), 44.0 (C-18), 48.8 (C-13), 50.9 (C-9), 51.1 (C21), 54.0 (C-17), 55.6 (C-5), 69.0 (C-6), 73.9 (C-22), 79.1 (C-3). HR-ESI-MS m/z: $[\mathrm{M}-\mathrm{H}]^{-}=$ 459.3840 (calcd. for $\mathrm{C}_{30} \mathrm{H}_{51} \mathrm{O}_{3}{ }^{-}, 459.3843$ ).

$2^{\prime}-O-M e t h y l n o r d i v a r i c a t i c ~ a c i d ~(3)$. Brownish orange solid, MP. $149-151^{\circ} \mathrm{C}$. HR-ESI-MS $\mathrm{m} / z$ : $[\mathrm{M}-\mathrm{H}]^{-}=387.1449$ (calcd. for $\mathrm{C}_{21} \mathrm{H}_{23} \mathrm{O}_{7}^{-}$, 387.1449). IR $v_{\max }\left(\mathrm{cm}^{-1}\right):=3408,2962,2933,2873,1651$, 1615, 1586, 1432, 1249, 1206, 1160, 1140, 1043, 956, 826. ${ }^{1} \mathrm{H}-\mathrm{NMR}$ and ${ }^{13} \mathrm{C}-\mathrm{NMR}$ (see Table 2).

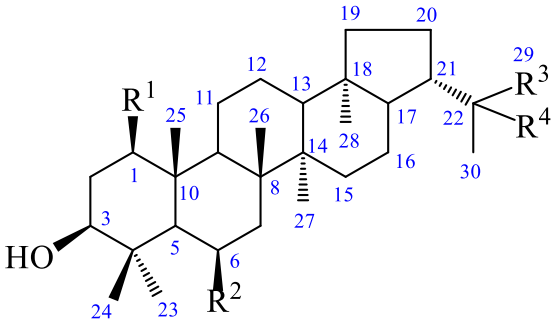

1: $\mathrm{R}^{1}=\mathrm{OAc}, \mathrm{R}^{2}=\mathrm{H}, \mathrm{R}^{3}=\mathrm{COOH}, \mathrm{R}^{4}=\mathrm{H}$ 2: $\mathrm{R}^{1}=\mathrm{H}, \mathrm{R}^{2}=\mathrm{OH}, \mathrm{R}^{3}=\mathrm{CH}_{3}, \mathrm{R}^{4}=\mathrm{OH}$

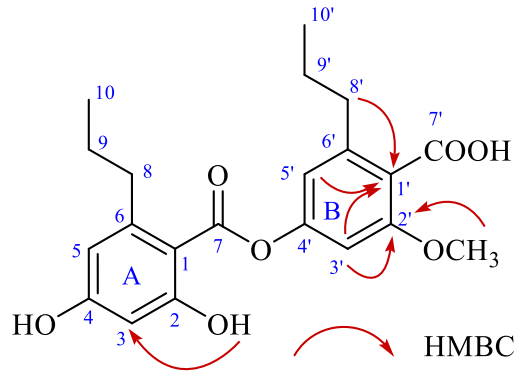

3

Figure 1. The structure of compound (1-3) and the selected key HMBC correlations of compound $\mathbf{3}$

\section{Results and Discussion}

\subsection{Structure Elucidation of Compound 1}

Compound $\mathbf{1}$ appeared as a white solid. Mass spectra exhibited a pseudo-molecular ion at 515.3734 (calcd. for $\mathrm{C}_{32} \mathrm{H}_{53} \mathrm{O}_{5}{ }^{-}, 515.3736$ ), which corresponded with $\mathrm{C}_{32} \mathrm{H}_{52} \mathrm{O}_{5}$. The FT-IR spectrum displayed the existence of a hydroxy moiety at $3418 \mathrm{~cm}^{-1}$ together with two carbonyl groups at 1732 and $1716 \mathrm{~cm}^{-1}$. The ${ }^{1} \mathrm{H}-\mathrm{NMR}$ indicated that there were 7 methyl groups attached to quaternary carbon and one methyl group at $\delta_{\mathrm{H}} 1.13(3 \mathrm{H}, d)$ attached to methine carbon. Furthermore, two peaks at $\delta_{\mathrm{H}}$ $4.59(1 \mathrm{H}, d d)$ and $3.31(1 \mathrm{H}, d d)$ were deduced for two oxygenated methine carbons. The ${ }^{13} \mathrm{C}-\mathrm{NMR}$ and DEPT revealed 32 signals, two of which were oxygenated methine carbons at $\delta \mathrm{C} 80.9(\mathrm{C}-1)$ and 75.2 (C-3). Further analysis carbon spectrum showed resonance signals of two carbonyl groups at $\delta_{\mathrm{C}}$ $170.5\left(\mathrm{C}-1^{\prime}\right)$ and $183.6(\mathrm{C}-29)$ which were well-matched to FT-IR. For these initial analysis, it is proved that compound 1 shared some similarities with $3 \beta$-hydroxyhopan-29-oic acid $[10,11]$ except for the presence of an additional acetoxy group.

In HMBC spectrum, proton $\mathrm{H}-2$ exhibited correlations with both oxygenated methine carbons at $\delta_{\mathrm{C}} 80.9(\mathrm{C}-1)$ and $75.2(\mathrm{C}-3)$. Moreover, methine proton at $\delta_{\mathrm{H}} 4.59(\mathrm{H}-1)$ interacted with the other oxygenated methine carbon at $\delta_{\mathrm{C}} 75.2(\mathrm{C}-3)$ together with C-9,10. Besides, the proton at $\delta_{\mathrm{H}} 3.31(\mathrm{H}-3)$ gave cross-signals with two methyl groups C-23 and C-24. These above data evidenced that two oxygenated methine carbons were located at C-1 and C-3. The position of the acetoxy group was confirmed at $\mathrm{C}-1$ as indicated by a cross-peak between $\mathrm{H}-1$ at $4.59(1 \mathrm{H}, d d)$ and carbonyl carbon at $\delta_{\mathrm{C}}$ $170.5\left(\mathrm{C}-1^{\prime}\right)$. Further analyzing HMBC indicated that both protons at $\delta_{\mathrm{H}} 1.13(\mathrm{H}-30)$ and $2.36(\mathrm{H}-22)$ showed cross-signals with a carboxyl group at $\delta_{\mathrm{C}} 183.6$ (C-29); therefore, the position of carboxylic acid moiety was logically deduced for attaching to C-22 (Figure 2a). 


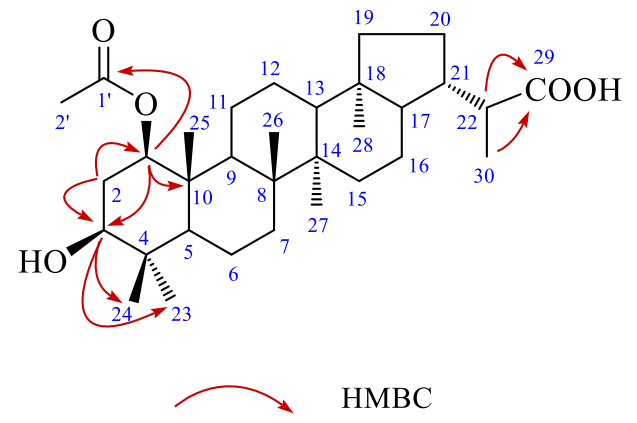

(a)

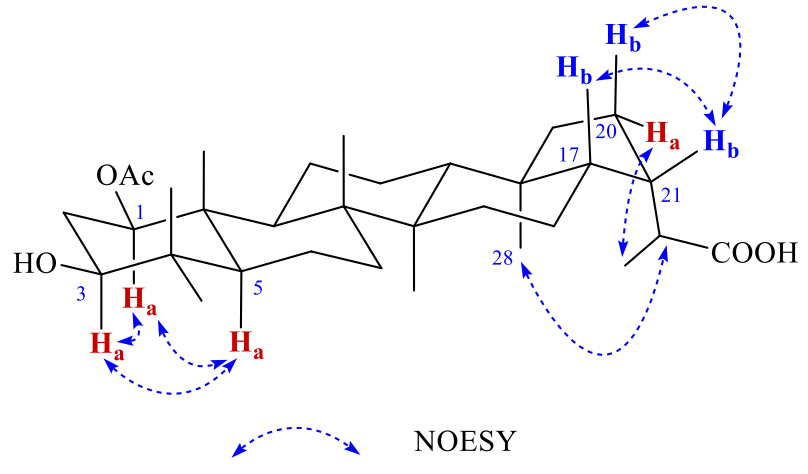

(b)

Figure 2. The selected key HMBC (a) and NOESY $(b)$ correlations of compound 1

The relative stereochemistry of C-1, C-3 was unambiguously identified by NOESY spectrum (Figure $2 b$ ). Three protons including H-1, H-3, H-5 exhibited pair-to-pair interactions, which can be firmly concluded that these protons were oriented on the same side. In addition, due to the rigidity of pentacyclic skeleton, the H-5 must be downward, and as a result, the conformation of C-1 and C-3 were both beta. From all the above data, compound 1 was readily interpreted as $1 \beta$-acetoxy- $3 \beta$ hydroxy-21 $\alpha$-hopan-29-oic acid and this was a new compound.

\subsection{Structure Elucidation of Compound 3}

Compound 3 was a brownish orange solid. The negative HRESI-MS exhibited a signal at $387.1449[\mathrm{M}-\mathrm{H}]^{-}$(calcd. for $\mathrm{C}_{21} \mathrm{H}_{23} \mathrm{O}_{7}^{-}, 387.1449$ ) which was deduced for chemical formula $\mathrm{C}_{21} \mathrm{H}_{24} \mathrm{O}_{7}$. The ${ }^{1} \mathrm{H}-\mathrm{NMR}$ spectrum indicated the presence of two pairs of meta coupling at $\delta_{\mathrm{H}} 6.39(1 \mathrm{H}$, $d, 2.5 \mathrm{~Hz}, \mathrm{C}-3) ; 6.45(1 \mathrm{H}, d, 2.5 \mathrm{~Hz}, \mathrm{C}-5)$ and $6.57\left(1 \mathrm{H}, d, 2.5 \mathrm{~Hz}, \mathrm{C}-3^{\prime}\right) ; 6.50\left(1 \mathrm{H}, d, 2.5 \mathrm{~Hz}, \mathrm{C}-5^{\prime}\right)$, suggested for two tetrasubstituted benzene rings. In the upfield region, there were proton signals of two $n$-propyl side chains at $\delta_{\mathrm{H}} 2.95(2 \mathrm{H}, \mathrm{H}-8) ; 1.70(2 \mathrm{H}, m, \mathrm{H}-9) ; 0.95(3 \mathrm{H}, t, \mathrm{H}-10)$ and $3.12(2 \mathrm{H}, t$, $\left.\mathrm{H}-8^{\prime}\right) ; 1.63\left(2 \mathrm{H}, m, \mathrm{H}-9^{\prime}\right) ; 0.90\left(3 \mathrm{H}, t, \mathrm{H}-10^{\prime}\right)$. Furthermore, a singlet signal at $3.86\left(s, 2^{\prime}-\mathrm{OCH}_{3}\right)$ was proposed for a methoxy group. In the downfield of spectra, there were two signals of hydroxy groups, one of which at $\delta_{\mathrm{H}} 11.17(1 \mathrm{H}, s, 2-\mathrm{OH})$ was a chelated hydroxy group, the remaining at $\delta_{\mathrm{H}} 14.22(1 \mathrm{H}$, brs, - $\mathrm{COOH}$ ) was assigned for carboxylic acid moiety. Independently, the ${ }^{13} \mathrm{C}-\mathrm{NMR}$ and DEPT spectra were also evidenced for two $n$-propyl side chains at $\delta_{\mathrm{C}} 39.3$ (C-8); 25.9 (C-9); 14.4 (C-10) and $38.0\left(\mathrm{C}-8^{\prime}\right) ; 25.5\left(\mathrm{C}-9^{\prime}\right) ; 14.4\left(\mathrm{C}-10^{\prime}\right)$; four unsubstituted aromatic carbon at $\delta_{\mathrm{C}} 99.8(\mathrm{C}-3), 111.3(\mathrm{C}-$ 5), $114.5\left(\mathrm{C}-3^{\prime}\right), 108.2\left(\mathrm{C}-5^{\prime}\right)$; and one methoxy carbon at $\delta_{\mathrm{C}} 55.9\left(2^{\prime}-\mathrm{OCH}_{3}\right)$. The other characteristics derived from these spectra were two carbonyl signals at $\delta_{\mathrm{C}} 170.2$ (C-7) and 176.7 (C-7'). In brief, these spectroscopic data indicated key similarity with divaricatic acid, yet compared with published data of divaricatic acid in different solvents, its spectra data showed some minor distinction [Table S3] [12, 13]. From the above evidence, the structure of compound $\mathbf{3}$ was initially interpreted as an isomer of divaricatic acid.

The structure of this compound was not divaricatic acid 3a as the above discussion. It meant that the methoxy group did not locate at $\mathrm{C}-4$. Thus, two possible isomers were that the methoxy group resided at $\mathrm{C}-2$ in 2-O-methylnordivaricatic acid $\mathbf{3 b}$ (Figure S2) or at $\mathrm{C}-2^{\prime}$ in $2^{\prime}-O$-methylnordivaricatic acid 3 (Figure 1). In this case, the position of methoxy group could be literally determined by HMBC correlation. Firstly, for a typical depside derivative, the aromatic carbon-bearing ester group C-1 generally shifted to upfield region compared to carboxylic acid moiety at $\mathrm{C}-1^{\prime}$ as in case of divaricatic acid 3a (Table S3) [12]. The HMBC analysis revealed that three protons including H-3', 5', 8' gave correlated peaks with nearby $\mathrm{C}-1^{\prime}$. In addition, both proton of methoxy group and $\mathrm{H}-3^{\prime}$ correlated with C-2' (Table 2). As a result, the methoxy group must reside in B-ring at C-2'. Secondly, the deeper analysis $\mathrm{HMBC}$ revealed that the $2-\mathrm{OH}$ proton of compound $\mathbf{3}$ also showed a three-bond correlation with $\mathrm{C}-3$ but not with $\mathrm{C}-3$ '. This result confirmed that the $2-\mathrm{OH}$ was located in A ring, and the methoxy group must be bound to $\mathrm{C}-2^{\prime}$. In brief, the above analysis from HMBC supported the 
methoxy group located in B-ring and it can be deduced that compound $\mathbf{3}$ was $2^{\prime}-O$ methylnordivaricatic acid, which was a novel compound.

Table 1. The spectroscopic data of compound $\mathbf{1}\left(\mathrm{CDCl}_{3}, \delta\right.$ in $\mathrm{ppm}, \mathrm{J}$ in $\left.\mathrm{Hz}\right)$

\begin{tabular}{|c|c|c|c|c|}
\hline Position & $\begin{array}{l}{ }^{13} \mathbf{C}-\mathbf{N M R} \\
(150 \mathrm{MHz})\end{array}$ & $\begin{array}{c}{ }^{\mathbf{1}} \mathbf{H}-\mathbf{N M R} \\
(600 \mathrm{MHz})\end{array}$ & $\begin{array}{c}\text { HMBC } \\
\left({ }^{1} \mathrm{H} \rightarrow{ }^{13} \mathrm{C}\right)\end{array}$ & $\begin{array}{c}\text { NOESY } \\
\left({ }^{1} \mathrm{H} \rightarrow{ }^{1} \mathrm{H}\right)\end{array}$ \\
\hline 1 & 80.9 & $4.59(1 \mathrm{H}, d d, 11.34 \& 4.62 \mathrm{~Hz})$ & $\mathrm{C}-2,3,9,10,25,1^{\prime}$ & $2 \alpha, 2 \beta, 3,5,9,23$ \\
\hline \multirow[t]{2}{*}{2} & 33.4 & $1.91\left(1 \mathrm{H}, m, \mathrm{H}_{\alpha}\right)$ & $\mathrm{C}-1,3,4,10$ & $1,2 \beta, 3$ \\
\hline & & $1.62\left(1 \mathrm{H}, m, \mathrm{H}_{\beta}\right)$ & $\mathrm{C}-1,3,4,10$ & $1,2 \alpha, 24,32$ \\
\hline 3 & 75.2 & $3.31(1 \mathrm{H}, d d, 12.24 \& 4.26 \mathrm{~Hz})$ & $\mathrm{C}-1,2,4,5,23,24$ & $1,2 \alpha, 5,23$ \\
\hline 4 & 38.8 & - & & \\
\hline 5 & 53.0 & $0.65(1 \mathrm{H}, d d, 11.58 \& 2.04 \mathrm{~Hz})$ & $\mathrm{C}-1,3,4,6,7,9,10,23,24,25$ & $1,3,6 \alpha, 9,23$ \\
\hline \multirow[t]{2}{*}{6} & 17.9 & $1.57\left(1 \mathrm{H}, m, \mathrm{H}_{\alpha}\right)$ & & 5,23 \\
\hline & & $1.49\left(1 \mathrm{H}, m, \mathrm{H}_{\beta}\right)$ & $\mathrm{C}-26$ & 24 \\
\hline \multirow[t]{2}{*}{7} & 33.1 & $1.40\left(1 \mathrm{H}, m, \mathrm{H}_{\alpha}\right)$ & $\mathrm{C}-26$ & $7 \beta$ \\
\hline & & $1.21\left(1 \mathrm{H}, m, \mathrm{H}_{\beta}\right)$ & $\mathrm{C}-5,6,8,9,26$ & $7 \alpha, 26$ \\
\hline 8 & 42.2 & - & & \\
\hline 9 & 50.7 & $1.45(1 \mathrm{H}, m)$ & C-9 & $1,5,23,27$ \\
\hline 10 & 42.2 & - & & \\
\hline 11 & 23.0 & $1.46(2 \mathrm{H}, \mathrm{m})$ & & 32 \\
\hline \multirow[t]{2}{*}{12} & 23.8 & $1.46(1 \mathrm{H}, m)$ & $\mathrm{C}-13$ & \\
\hline & & $1.32(1 \mathrm{H}, m)$ & C-9, 13 & \\
\hline 13 & 48.6 & $1.32(1 \mathrm{H}, m)$ & & \\
\hline 14 & 41.9 & - & & \\
\hline \multirow[t]{2}{*}{15} & 33.5 & $1.16\left(1 \mathrm{H}, m, \mathrm{H}_{\alpha}\right)$ & $\mathrm{C}-13,16,17,27$ & $15 \beta, 27,16 \beta$ \\
\hline & & $1.32\left(1 \mathrm{H}, m, \mathrm{H}_{\beta}\right)$ & $\mathrm{C}-16$ & $15 \alpha, 26$ \\
\hline \multirow[t]{2}{*}{16} & 19.8 & $1.28\left(1 \mathrm{H}, m, \mathrm{H}_{\alpha}\right)$ & & \\
\hline & & $1.48\left(1 \mathrm{H}, m, \mathrm{H}_{\beta}\right)$ & $\mathrm{C}-14,15,17,18$ & $15 \alpha, 21$ \\
\hline 17 & 53.6 & $1.25(1 \mathrm{H}, m)$ & C- $16,18,20,21,28$ & 21 \\
\hline 18 & 44.3 & - & & \\
\hline \multirow[t]{2}{*}{19} & 40.9 & $1.51\left(1 \mathrm{H}, m, \mathrm{H}_{\alpha}\right)$ & $\mathrm{C}-17,18,20,21,28$ & 28 \\
\hline & & $0.90\left(1 \mathrm{H}, m, \mathrm{H}_{\beta}\right)$ & C-18 & $17,19 \alpha, 20 \beta$ \\
\hline \multirow[t]{2}{*}{20} & 26.6 & $1.43\left(1 \mathrm{H}, m, \mathrm{H}_{\alpha}\right)$ & & $22,20 \beta, 30$ \\
\hline & & $1.87\left(1 \mathrm{H}, m, \mathrm{H}_{\beta}\right)$ & $\mathrm{C}-17,18,19$ & $21,20 \alpha, 19 \alpha, 30$ \\
\hline 21 & 42.0 & $2.34(1 \mathrm{H}, m)$ & $\mathrm{C}-17,18,20,22$ & $16 \beta, 17,20 \beta, 30$ \\
\hline 22 & 42.8 & $2.36(1 \mathrm{H}, m)$ & $\mathrm{C}-21,29,30$ & $20 \alpha, 28,30$ \\
\hline 23 & 27.9 & $0.97(3 \mathrm{H}, s)$ & $\mathrm{C}-3,4,5,24$ & $1,3,5,6 \alpha, 9,24$ \\
\hline 24 & 15.0 & $0.77(3 \mathrm{H}, s)$ & $\mathrm{C}-3,4,5,23$ & $2 \beta, 6 \beta, 23$ \\
\hline 25 & 12.8 & $0.98(3 \mathrm{H}, s)$ & $\mathrm{C}-1,5,9,10$ & \\
\hline 26 & 16.9 & $0.94(3 \mathrm{H}, s)$ & $\mathrm{C}-7,8,9$ & $7 \beta, 15 \beta$ \\
\hline 27 & 16.6 & $0.91(3 \mathrm{H}, s)$ & $\mathrm{C}-8,13,15$ & $9,15 \alpha, 28$ \\
\hline 28 & 15.7 & $0.70(3 \mathrm{H}, s)$ & $\mathrm{C}-13,17,18,19$ & $22,27,19 \alpha$ \\
\hline 29 & 183.6 & - & & \\
\hline 30 & 17.6 & $1.13(3 \mathrm{H}, d, 6.48 \mathrm{~Hz})$ & C-21, 22, 29 & $20 \alpha, 20 \beta, 21,22$ \\
\hline $\mathbf{1}^{\prime}$ & 170.5 & - & $\mathrm{C}-1,2^{\prime}$ & \\
\hline $\mathbf{2}^{\prime}$ & 21.9 & $1.99(3 \mathrm{H}, s)$ & $\mathrm{C}-1^{\prime}$ & $2 \beta, 11$ \\
\hline
\end{tabular}


Table 2. The spectroscopic data of compound $\mathbf{3}$ (Acetone- $d 6, \delta$ in ppm, $\mathrm{J}$ in $\mathrm{Hz}$ )

\begin{tabular}{|c|c|c|c|}
\hline Position & $\begin{array}{c}{ }^{13} \mathbf{C}-\mathbf{N M R} \\
(125 \mathrm{MHz})\end{array}$ & $\begin{array}{c}{ }^{1} \mathbf{H}-\mathbf{N M R} \\
(500 \mathrm{MHz})\end{array}$ & $\begin{array}{c}\text { HMBC } \\
\left({ }^{1} \mathrm{H} \rightarrow{ }^{13} \mathrm{C}\right)\end{array}$ \\
\hline 1 & 105.7 & - & \\
\hline 2 & 166.1 & - & \\
\hline 3 & 99.8 & $6.39(1 \mathrm{H}, d, 2.5 \mathrm{~Hz})$ & $C-1,2,5$ \\
\hline 4 & $165.3 *$ & - & \\
\hline 5 & 111.3 & $6.45(1 \mathrm{H}, d, 2.5 \mathrm{~Hz})$ & $\mathrm{C}-1,3,4,8$ \\
\hline 6 & 148.4 & - & \\
\hline 7 & 170.2 & - & \\
\hline 8 & 39.3 & $2.95(2 \mathrm{H})^{\#}$ & $\mathrm{C}-1,5,6,9,10$ \\
\hline 9 & 25.9 & $1.70(2 \mathrm{H}, m)$ & $\mathrm{C}-6,8,10$ \\
\hline 10 & 14.4 & $0.95(3 \mathrm{H}, t, 7.0 \mathrm{~Hz})$ & C-8, 9 \\
\hline $\mathbf{1}^{\prime}$ & 116.2 & - & \\
\hline $\mathbf{2}^{\prime}$ & $165.3^{*}$ & - & \\
\hline $3^{\prime}$ & 114.5 & $6.57(1 \mathrm{H}, d, 2.5 \mathrm{~Hz})$ & $\mathrm{C}-1^{\prime}, 2^{\prime}, 4^{\prime}, 5^{\prime}$ \\
\hline $4^{\prime}$ & 152.8 & - & \\
\hline $5^{\prime}$ & 108.2 & $6.50(1 \mathrm{H}, d, 2.5 \mathrm{~Hz})$ & $\mathrm{C}-1^{\prime}, 3^{\prime}, 4^{\prime}, 8^{\prime}$ \\
\hline $6^{\prime}$ & 149.3 & - & \\
\hline $7^{\prime}$ & 176.7 & - & \\
\hline $8^{\prime}$ & 38.0 & $3.12(2 \mathrm{H}, t, 7.5 \mathrm{~Hz})$ & $\mathrm{C}-1^{\prime}, 5^{\prime}, 6^{\prime}, 9^{\prime}, 10^{\prime}$ \\
\hline $9^{\prime}$ & 25.5 & $1.63(2 \mathrm{H}$, sextet, $7.5 \mathrm{~Hz})$ & $\mathrm{C}-6^{\prime}, 8^{\prime}, 10^{\prime}$ \\
\hline $10^{\prime}$ & 14.4 & $0.90(3 \mathrm{H}, t, 7.0 \mathrm{~Hz})$ & $\mathrm{C}-8^{\prime}, 9^{\prime}$ \\
\hline 2-OH & - & $11.17(1 \mathrm{H}, s)$ & $\mathrm{C}-3$ \\
\hline $2^{\prime}-\mathrm{OCH}_{3}$ & 55.9 & $3.86(3 \mathrm{H}, s)$ & $\mathrm{C}-2^{\prime}$ \\
\hline$-\mathrm{COOH}$ & - & $14.22(1 \mathrm{H}, b r s)$ & \\
\hline
\end{tabular}

Although the structure of compound $\mathbf{2}$ has been recorded, the referenced spectroscopic data were not available for comparison. In this study, we fully reported the spectroscopic assignment for this compound (see Table S2). In addition, this compound was firstly isolated from $D$. applanata.

In combination with the previous report [8], we have isolated six phenolic compounds, one depside, two lichenxanthones, and three hopane triterpenoids. They complement to phytochemical database of $D$. applanata. Hopane triterpenoid, especially $3 \beta$-acetoxyhopane-1 $\beta, 22$-diol, was recorded in Dirinaria genus [9]. Our results in chemical composition of $D$. applanata have identified three hopane triterpenoids which are hydroxylated at C-3 position whereas the hydroxylation of those hopanes in other lichen genus occurred at C-6 [14, 15]; C-6, 7 [16]; C-6, 15 [17]; C-6, 16 [18]; C-6, 7, 15 [19] or C-6, 7, 16 [20]. This means that 3-hydroxyhopane derivatives could be recognized as a fingerprint for D. applanata. In addition, divaricatic acid 3a, a depside, is recorded in Dirinaria genus [9]. A new 2'-O-methylnordivaricatic acid $\mathbf{3}$, an isomer of 3a, could be generated from the late-stage functionalization in biosynthesis pathway of Dirinaria species. These findings might contribute to chemotaxonomy for determining $D$. applanata among a pool of lichen species.

In conclusion, from the extract of the lichen Dirinaria applanata, three compounds were isolated and fully characterized by both 1D and 2D-NMR. Notably, compound $\mathbf{1}$ was a new hopanoic acid while compound $\mathbf{3}$ was a new depside. Moreover, compound $\mathbf{2}$ was firstly isolated from D.applanata. 


\section{Acknowledgements}

This study is funded in part by the Can Tho University Improvement Project VN14-P6, supported by Japanese ODA loan.

\section{Supporting Information}

Supporting information accompanies this paper on http://www.acgpubs.org/journal/records-ofnatural-products

\section{ORCID}

Nguyen Trong Tuan: 0000-0003-2132-113X

Mai Van Hieu: 0000-0002-5077-2899

Nguyen Quoc Chau Thanh: 0000-0001-5128-4654

Huynh Van Loi: 0000-0003-2065-3829

Lai Huu Nghia: 0000-0003-1276-3227

Tran Thi Tuyet Hoa: 0000-0002-5894-7980

Kenji Kanaori: 0000-0002-0142-9613

\section{References}

[1] I. I. I. Nash and H. Thomas (2008). Lichen Biology, Cambridge University Press, Cambridge.

[2] M. J. Calcott, D. F. Ackerley, A. Knight, R. A. Keyzers and J. G. Owen (2018). Secondary metabolism in the lichen symbiosis, Chem. Soc. Rev. 47, 1730-1760.

[3] G. Shrestha and L. L. S. Clair (2013). Lichens: a promising source of antibiotic and anticancer drugs, Phytochem. Rev. 12, 229-244.

[4] V. P. Zambare and L. P. Christopher (2012). Biopharmaceutical potential of lichens, J. Pharm. Biol. 50, 778-798.

[5] Y. Yamamoto, K. Hara, H. Kawakami and M. Komine, (2015), Lichen substances and their biological activities, In: Recent Advances in Lichenology. Springer, 181-199.

[6] U. Jayalal, S. S. Oh, S. Joshi, S. O. Oh and J. S. Hur (2013). The lichen Dirinaria picta new to South Korea, Mycobiology 41, 155-158.

[7] E. Ahmed, W. Elkhateeb, H. Taie, M. Rateb and W. Fayad (2017). Biological capacity and chemical composition of secondary metabolites from representatives Japanese lichens, J. Appl. Pharm. Sci. 7, 98103.

[8] T. T. Nguyen, Q. C. T. Nguyen, V. H. Mai, Q. T. Phan, P. Q. Do, T. D. Nguyen, P. D. Nguyen, T. T. T. Nguyen, T. D. Le, T. X. T. Dai, K. Kamei and K. Kanaori (2019). A new hopane derivative from the lichen Dirinaria applanata, Nat. Prod. Res., 1-5 (in press). DOI: 10.1080/14786419.2019.1644511

[9] J. A. Elix (2009). Dirinaria, Fl. Australia. 57, 509-517.

[10] S. Huneck and I. Yoshimura (1996). Identification of lichen substances, Springer

[11] D. Joulain and R. Tabacchi (2009). Lichen extracts as raw materials in perfumery. Part 1: oakmoss, Flavour Frag. J. 24, 49-61.

[12] L. F. G. Brandão, G. B. Alcantara, M. F. C. Matos, D. Bogo, D. Dos Santos Freitas, N. M. Oyama and N. K. Honda (2013). Cytotoxic evaluation of phenolic compounds from lichens against melanoma cells, Chem. Pharm. Bull. 61, 176-183.

[13] P. Kumboonma, T. Senawong, S. Saenglee, C. Yenjai and C. Phaosiri (2018). New histone deacetylase inhibitors from the twigs of Melanorrhoea usitata, Med. Chem. Res. 27, 2004-2015.

[14] C. Seo, J. HanYim, H. Kum Lee and H. Oh (2011). PTP1B inhibitory secondary metabolites from the Antarctic lichen Lecidella carpathica, Mycology 2, 18-23.

[15] G. M. König and A. D. Wright (1999). ${ }^{1} \mathrm{H}$ and ${ }^{13} \mathrm{C}-\mathrm{NMR}$ and biological activity investigations of four lichen-derived compounds, Phytochem. Anal. 10, 279-284.

[16] M. Cuellar, W. Quilhot, C. Rubio, C. Soto, L. Espinoza and H. Carrasco (2008). Phenolics, depsides and triterpenes from the chilean lichen Pseudocyphellaria nudata (Zahlbr.) DJ Galloway, J. Chil. Chem. Soc. 53, 1624-1625.

[17] D. T. M. Nguyen, L. T. M. Do, H. T. N. Tuyet, M. K. Q. Ho, H. T. Nguyen, J. Mortier and P. K. P. Nguyen (2019). Chemical constituents of the lichen Dendriscosticta platyphylloides, Lobariaceae, Sci. Technol. Dep. J. 22, 165-172. 
[18] J. Sichaem, H. H. Nguyen and T. H. Duong (2019). Hopane-6 $\alpha$, 16 $\alpha$, 22-triol: A new hopane triterpenoid from the lichen Parmotrema sancti-angelii, Nat. Prod. Commun. 14, 1934578X19858208.

[19] R. Corbett and A. Wilkins (1977). Lichens and fungi. XV. Revised structures for hopane triterpenoids isolated from the lichen Pseudocyphellaria mougeotiana, Aust. J. Chem. 30, 2329-2332.

[20] M. C. Fritis, C. R. Lagos, N. Q. Sobarzo, I. M. Venegas, C. S. Sánchez, H. C. Altamirano, L. E. Catalán and W. Q. Palma (2013). Depsides and triterpenes in Pseudocyphellaria coriifolia (lichens) and biological activity against Trypanosoma cruzi, Nat. Prod. Res. 27, 1607-1610.

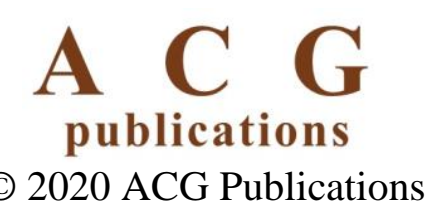

